\title{
Exploring the impacts of protected area tourism on local communities using a resilience approach
}

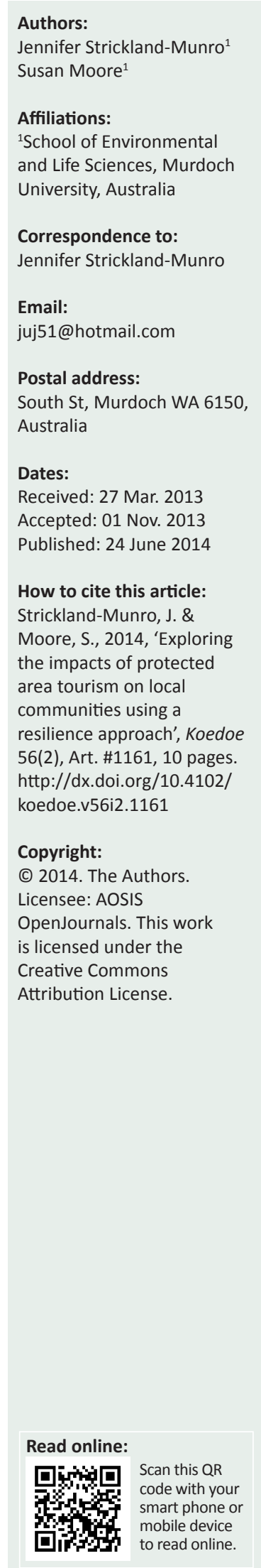

As the protected area mandate expands to include social equity, the impacts of parks and their tourism on neighbouring indigenous and local communities is receiving growing practical and theoretical interest. This article reported on one such study, which explored the impacts of protected area tourism on communities bordering the iconic Kruger National Park in South Africa and Purnululu National Park in Australia. The study drew on interviews with park staff, tourism operators and community members. Guided by a conceptual framework grounded in resilience thinking, interactions amongst the parks, tourism and local communities were revealed as complex, contested and multi-scalar. Underlying drivers included cultural norms and values based on nature, entrenched poverty, poor Western education and economic opportunities associated with tourism. Park tourism offered intrinsic opportunities and benefits from nature conservation and associated intangible cultural values. More tangible benefits arose through employment. Damage-causing animals and visitation difficulties were negative impacts. Interaction with tourists was limited, with a sense of disconnect evident. Findings indicated the need for multifaceted, carefully considered policy responses if social equity and benefits for local communities are to be achieved. Framing the impacts of protected area tourism through the resilience framework provided a useful way to access local community perceptions whilst retaining awareness of the broader multi-scalar context in which interactions occur.

Conservation implications: Perceptions of separation and lack of education to engage in economic opportunities are major issues. Intrinsic appreciation of parks is an important platform for building future opportunities. Accrual of future benefits for local communities from park tourism depends on developing diverse economic opportunities, building community capacity and managing expectations and addressing economic disadvantage.

\section{Introduction}

Protected areas and tourism have a longstanding and mutually beneficial relationship (Bushell, Staiff \& Eagles 2007; Reinius \& Fredman 2007). Such areas offer a unique, desirable setting for the tourism product, whilst tourism offers park managers a revenue source that can assist ongoing conservation efforts. Beyond this mutual association, protected area tourism can have considerable benefits for surrounding communities, as well as social costs (e.g. increased competition for resources and facilities). Whether the opportunities provided by tourism benefit communities or not is debatable and contingent on a number of interacting factors.

Increasingly, protected area tourism is being recognised as a complex social-ecological system, with interactions characterised by dynamism, complexity, uncertainty, unpredictability and multi-scalar connections (McCool 2009; Strickland-Munro, Allison \& Moore 2010) (Figure 1). Local communities are an integral part of this system, as described by Strickland-Munro et al. (2010) using a resilience approach. Unpredictable and susceptible to external influences beyond local control, a number of barriers can obstruct the delivery of benefits to local communities and confound interactions between protected areas, tourism and local communities.

A resilience approach, which acknowledges the importance of understanding interactions between system components, provides a promising alternative to reductionist analyses. A broader, interdisciplinary approach cognisant of multiple interacting variables and perspectives allows exploration of the complex relationships amongst system components (Farrell \& TwiningWard 2005). Resilience thinking offers one such framework and is particularly suited to protected area tourism's inherently 'messy' environment of complexity, change and uncertainty (McCool 2009; Plummer \& Fennell 2009). Resilience perspectives focus on understanding the dynamics of systems interactions and explicitly acknowledge system uncertainty, complexity and dynamism (Resilience Alliance 2007a, 2007b; Walker et al. 2006). Published applications of resilience perspectives to protected area tourism however have been limited to date. 
This article applies a conceptual framework based on resilience thinking to an exploration of the impacts of tourism associated with protected areas on local communities. The framework was used for local communities adjacent to Kruger National Park in South Africa and Purnululu National Park in Australia. Specifically, the study sought to ascertain key socio-economic impacts of protected area tourism on the local communities. Local perspectives were privileged, whilst the broader context was accommodated through the framework's attention to multi-scalar influences and interactions (Figure 1).

We first outline the role of protected area tourism in South Africa and Australia, followed by a brief synopsis of the tourism impact literature and the growing demand for park tourism to address social equity and deliver benefits to local communities. The research design and methods follows, with the first part of this section devoted to an overview of the resilience framework guiding this research. The two case study areas are then described as part of the comprehensive description of the case studies as protected area-tourism systems. The article's conclusion includes implications for park and tourism managers. Here we present one of the first published applications of resilience perspectives to protected area tourism and the investigation of such impacts on local communities. The combination of resilience perspectives with ethnographic research provides a synthesised, coherent approach facilitating in-depth insights into local impacts.

\section{Protected area tourism}

Protected area tourism fills a significant niche in both South Africa and Australia; this provides the initial rationale for selecting case studies in the two countries. Boasting diverse scenery and wildlife (Cornelissen 2005; Worboys, Lockwood \& De Lacy 2005), the respective protected areas of these countries offer extensive tourism opportunities and experiences. Visitation to protected areas in both countries continues to grow, providing valued revenue. In South Africa, visitation to protected areas grew by $0.5 \%$ from 2009 arrivals, to 4536491 arrivals in 2010-2011. Associated revenue for this period was R815.26 million (approx. \$99.09 million), an increase of $12.1 \%$ from the previous year (South African National Parks [SANParks] 2011). In Australia, nature tourism (based on parks and visits to zoos, aquaria and botanic gardens) contributes an estimated AUS $\$ 23$ billion (approx. \$23.85 billion) annually to the economy (Tourism Research Australia 2009).

Beyond this broad economic impact, protected area tourism is further valued for its touted ability to foster smaller scale socio-economic development and employment (Telfer \& Sharpley 2008). However, these socio-economic benefits often co-exist alongside negative impacts for the communities adjoining protected areas (Wall \& Mathieson 2006). Given links between benefit delivery and positive local perceptions of protected areas and tourism (e.g. Brockington, Duffy \& Igoe 2008), research into the impacts of park tourism on local communities is of considerable interest. Kruger National Park and Purnululu National Park offered promising case studies as they are both iconic, with communities living adjacent to them which have opportunities to engage in tourism but continue to face entrenched economic disadvantage.

\section{Tourism impacts}

Tourism impacts have been extensively documented (e.g. Wall \& Mathieson 2006). We confine our synopsis to impacts relevant to protected area tourism and local communities.

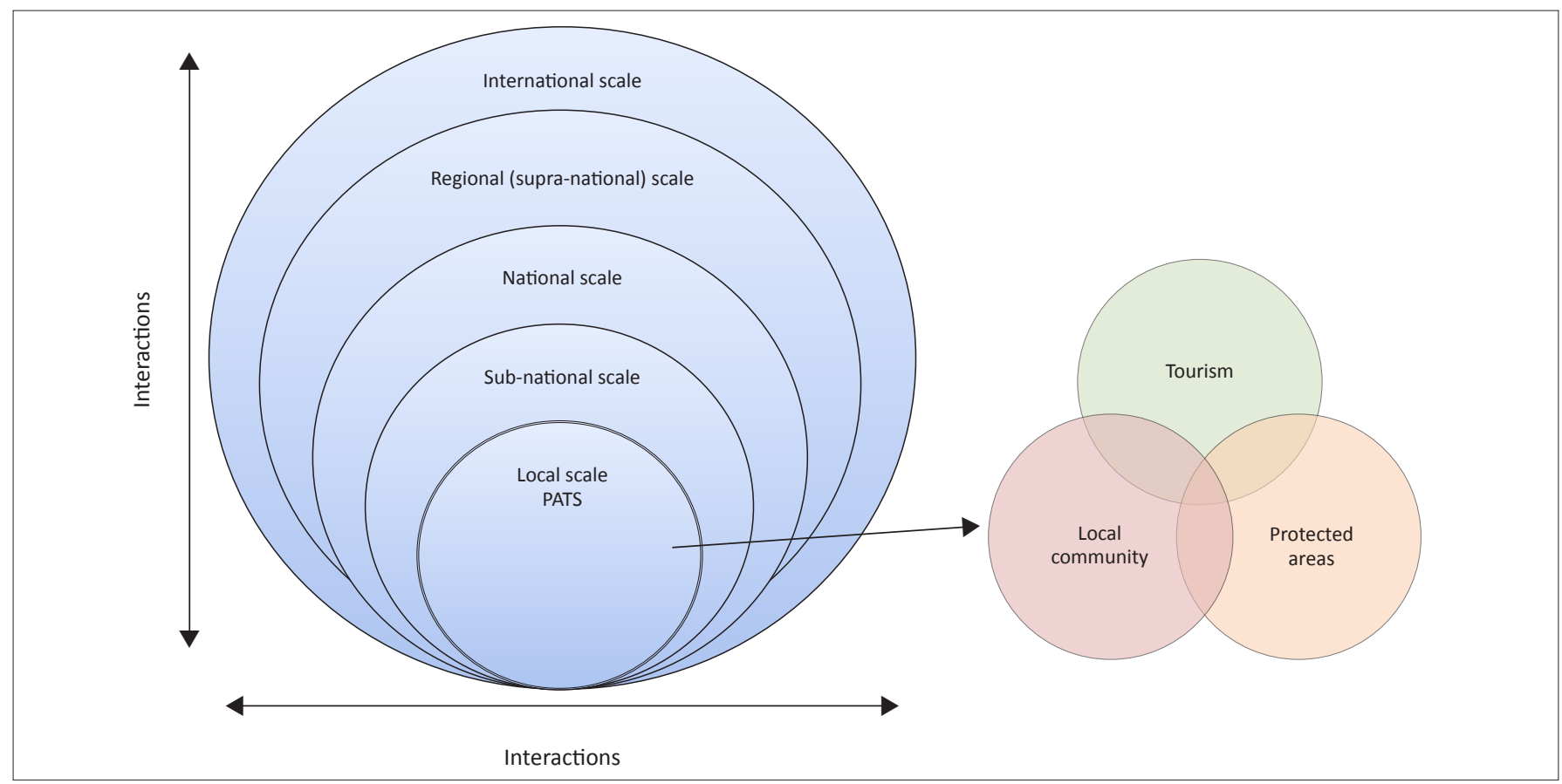

Source: Authors' own creation

PATS, protected area-tourism system.

FIGURE 1: Multi-scalar nature of protected area-tourism systems. 
The tangible economic impacts, notably employment opportunities, dominate the literature. Employment provides a direct economic link between local communities and park tourism and is recognised as one of tourism's main development advantages (e.g. Simelane, Kerley \& Knight 2006). This development role stems from the generation of both direct (e.g. roles in park or tourism operations) and indirect job opportunities (e.g. derivation of income from related activities such as curio sales), both of which can raise local incomes and living standards (Mill \& Morrison 2006). The need for such economic development via tourism is well recognised in South Africa, where poverty is endemic (Binns $\& \mathrm{Nel}$ 2002). Its necessity is often overlooked in Australia, where, in reality, living standards and economic development for many Indigenous Australians remain significantly below that of non-Indigenous Australians (Altman 2007).

Tourism can also have negative economic impacts. These include dependency and stifling of economic diversification (Telfer \& Sharpley 2008), as well as inequality in benefits (Simpson 2009; Trau \& Bushell 2008). Inequity of benefit distribution is heightened by 'enclave' tourism, where tourists and local communities are separated by boundaries (e.g. park fences), with community interactions typically limited to transient hawking at park entrances. Enclave tourism restricts local access to tourism markets and can also contribute to financial leakage (Mill \& Morrison 2006). Novelli and Scarth (2007), for example, report that tourists to Malawi's Liwonde National Park remain within park boundaries, limiting opportunities for interactions with locals. This distancing was linked to a lack of ownership for the Park. Furthermore, tourism's financial benefits are often overstated, leading to false expectations (Simpson 2008). Other negative economic impacts include lost opportunity costs, where tourism dominates resources that could have been more profitably used in other sectors (Mill \& Morrison 2006) such as agriculture.

Socio-cultural impacts include changes to individual behaviour, value systems, cultural practices and community organisations (Andereck et al. 2005). Tourism can enhance ethnic identity, increase understanding between cultures, challenge stereotypes and perceptions and revitalise cultural values and traditions (Telfer \& Sharpley 2008), including the use of natural resources. Changes to decision-making structures and involvement in park management are further positive impacts (Scherl \& Edwards 2007). Enrichment of local skills, local and institutional capacity building, investments in community infrastructures, such as schools and health care, and improved access to information and external environments are further positive impacts. Negative socio-cultural impacts include the loss or misuse of cultural resources, perceptions of cultural commoditisation and exploitation, 'demonstration effects' where locals adopt tourist behaviours and the marginalisation of locals to jobs of lesser importance (Telfer \& Sharpley 2008). Tourism may also cause culture shock, communication difficulties, tension, suspicion and hostility, segregation and perceptions of superiority or inferiority (Robinson 1999).
In recent years, social equity and the delivery of benefits to local communities have assumed a greater role in protected areas (Phillips 2003; Worboys et al. 2005). This is certainly true for park managers in the two protected areas of interest to this study, where official attention is directed towards redressing social and economic inequities facing previously disadvantaged communities. South Africa's Kruger National Park emphasises park-people relations and benefit sharing and seeks to increase the Park's legitimacy amongst neighbouring communities. Tourism, and the benefits it can engender, is a key means of achieving these goals (SANParks 2008). Similarly, managers of Australia's Purnululu National Park are guided by an official commitment to ensure Indigenous engagement and benefit from Park and tourism operations (Department of Environment and Conservation [DEC] 2008). However, both Parks evidence a dearth of social research, with research on the impacts of Park tourism on local communities scarce, despite calls for such from Park managers and other interested parties (e.g. SANParks 2008; UNESCO 2010). The study reported in this article addresses this deficit.

\section{Research method and design}

Research was guided by Strickland-Munro et al.'s (2010) conceptual framework for investigating the relationship between protected area tourism and local communities and was grounded in resilience thinking (Resilience Alliance 2007a, 2007b). Four interdependent stages of investigation, described in detail in Strickland-Munro et al. (2010), were modified to comprehensively describe the protected areatourism system and scale of analysis (Figure 2, phase 1),

Phase 1: System definition

- system components (e.g. a given protected area, tourism and appropriate stakeholders, including both local communities and communities of interest)

- scale (e.g. research focus at local scale)

- governance

Phase 2: Past system change

- drivers (e.g. population growth, culture, education) and disturbances (e.g. extreme weather events, terrorism, fluctuations in tourist visitation)

- historical profile to explore the role of past events

- adaptive cycle to explore past disturbance, drivers

- governance

Phase 3: Current system state

- key issues and interactions (e.g. biodiversity conservation, economic benefits, natural resource use)

- governance

Phase 4: Monitoring change

- future scenarios (e.g. fall in tourist numbers, ecosystem degradation)

- derive indicators to monitor change over time

- governance

- eventually develop thresholds

Source: Derived and adapted from Strickland-Munro et al. (2010) and the Resilience Alliance Source: Derived and adapted from Strickland-Munro et al. (2010) and the Resilience Alliance (2007a, 2007b). For more information on these sources, please see the reference list for the article, Strickland-Munio, J. \& Moore, S., 2014, tourism on local communities using a resilience approach', Koedoe 56(2), Art. \#1161, 10 pages. http://dx.doi.org/10.4102/koedoe.v56i2.1161

FIGURE 2: Conceptual framework for investigating the relationship between protected area tourism and local communities. 
followed by a detailed description of past system changes and current state of the system (Figure 2, phases 2 and 3). In all four phases, socio-political aspects, and especially governance, have been emphasised in contrast to much resilience thinking, which has a strong ecological emphasis and often downplays these aspects (Miller et al. 2010).

Phase 1 (Figure 2) concerns defining the system of interest - interactions between the National Parks, their tourism and associated local communities. Investigation prioritised local perspectives, given that the study's central interest was impacts on local communities. We focused on the local scale, geographically defined 'community' and prioritised social over ecological interactions. The views of other stakeholders at local, sub-national and national scales were included, however, to incorporate interests beyond the local (Strickland-Munro et al. 2010), with such a multi-scalar approach being central to resilience analyses (Resilience Alliance 2007a, 2007b).

Phase 2 (Figure 2) explores past system change, focusing on system drivers and historical influences affecting current conditions. Understanding these drivers and underlying processes influencing system change is necessary to develop appropriate management responses and is central to resilience analyses (Resilience Alliance 2007a, 2007b). Typically, drivers are grouped into categories, including socio-political, demographic, economic and biophysical, and classified as either 'slow' or 'fast' depending on the rate at which they influence change. Slow variables play an important role in controlling the protected area-tourism system (Strickland-Munro et al. 2010) and influence wellbeing and governance (Kofinas \& Chapin 2009), whereas fast variables tend to operate at smaller spatio-temporal scales and influence system interactions at a faster rate. Although the adaptive cycle heuristic is integral to this phase it was not considered further in this article, given its focus on the dynamics amongst fast and slow variables over time and scale, rather than giving explicit attention to impacts.

Phase 3 (Figure 2) focuses on the state of the current system and explored key issues, such as those relating to values, benefits, conflicts, challenges and governance. Phase 4 (Figure 2) rests on monitoring changes in how protected areas, tourism and local communities interact. The final phase presented in this article differs from Strickland-Munro et al. (2010), as a lack of empirical information from the case studies on interactions meant that the threshold development advocated could not be undertaken. For this reason, this final phase was modified to recommend exploring future scenarios and developing indicators, both with the ultimate objective of further understanding interactions and eventually developing thresholds.

This article reported on the first three phases, with the aim of providing a thorough analysis of the impacts of protected area tourism on local communities. Future scenarios and indicator development, the fourth phase, are not included as they are less central to understanding impacts. For simplicity, a description of the impacts of governance is included in the second phase, although it is evident in all phases. Site selection was guided by three criteria, (1) the sites are iconic protected areas, (2) the protected areas have high tourism visitation and (3) they are neighboured by disadvantaged communities, that is, those with high unemployment, low incomes and poor education and health outcomes.

Information was obtained in this ethnographic study through semi-structured interviews with local community members, Park and tourism managers and staff, as well as government and non-government operatives. This wide range of people was selected to obtain the broadest possible worldview of how these local communities are experiencing tourism associated with their adjacent national park. New individuals were interviewed until 'theoretical saturation' (Bowen 2008) was reached, meaning that the particular interview did not add any new information. In this study, theoretical saturation was reached at 110 interviews (92 at Kruger, 18 at Purnululu). The interview questions covered perceived benefits, barriers to participation and other factors influencing the engagement of local communities with protected area tourism. These questions were asked to populate the conceptual framework in Figure 1 with information. Interviews were recorded where possible and transcribed verbatim, with trained local translators used in the South African study.

Analysis was undertaken using grounded theory, an inductive technique that generates theory from constant comparison of themes and patterns in interview transcripts. The code-based theory development software NVivo (QSR International 2008) facilitated analysis and assisted in the iterative refinement of conceptual codes. These codes, together with information gathered from document review and participant observation, informed the following results. Interview excerpts are provided to help describe these codes in the following section, a standard practice in reporting the results of grounded theory research. Review of historical and current literature regarding protected areas, tourism and local communities also contributed information.

\section{Results \\ Phase 1: System definition}

Both Parks in this protected area-tourism system are of iconic status: Kruger is world-renowned and acknowledged as the flagship of South African national parks (SANParks 2011), whilst Purnululu is listed a World Heritage site for its natural values (UNESCO 2010). Beyond these iconic ties, the Parks differ widely. Kruger dominates in physical size and scale of tourism, covering approximately 2 million ha and receiving 1.45 million tourists annually (SANParks 2013), in contrast to Purnululu's 208723 ha and current visitation of 24602 (DEC 2012). Operationally, Kruger has been in existence since 1926, whereas Purnululu's existence as a national park is much more recent, being formally gazetted in 1987 (Department of Conservation and Land Management [CALM] 1995). This disparity is reflected in Kruger's well 
developed tourist infrastructure, including 26 tourist rest camps with varied accommodation options and the broad range of visitor activities (SANParks 2008). Purnululu, however, has purposely adopted a minimalist approach to tourism development and offers only two public campsites with basic facilities. Several private camps offer a higher standard of accommodation. At the time of research, Kruger's workforce was 2116 permanent and temporary workers (Urban-Econ 2008), compared to Purnululu's complement of two permanent rangers and two Indigenous assistant rangers employed under Government welfare schemes.

Both Parks are accessible via road and air links and cater to self-drive visitors and group tours. However, Kruger's accessibility is far superior to Purnululu, particularly for road access, with Purnululu's unsealed $52 \mathrm{~km}$ entrance track requiring considerable skill and a suitable four-wheel drive vehicle to navigate. Additionally, Purnululu is affected by limited seasonal accessibility, with its open period restricted to April-December on account of the East Kimberley wet season (CALM 1995). Kruger remains open for business year round.

In terms of local communities, the Parks offer significant disparity as well as surprising analogies. Kruger is surrounded by densely populated ex-Bantustan communities, with the Park's southern and western borders ${ }^{1}$ home to over two million people (Department of Water Affairs and Forestry [DWAF] 2008). This research focused on two villages, Cork and Belfast, located closest to one of Kruger's busiest entrance gates. With a combined population of approximately 15000 residents, their location close to the Park offers opportunities for interactions with passing tourists. Purnululu, in contrast, is located in Australia's sparsely populated East Kimberley region, with a population density of 0.08 people $/ \mathrm{km}^{2}$ (Kimberley Development Commission n.d.). The Indigenous community of Warmun, with a population around 300 (Australian Bureau of Statistics 2006), is the Park's closest neighbour despite being located $50 \mathrm{~km}$ north-west of the Park. It was included in this study on account of this geographic proximity, as well as status at the time of research as 'gateway' community providing the last service facilities (e.g. petrol station, tourist accommodation and general store) available before entering the Park. In addition, many Indigenous residents retain strong cultural ties to the Purnululu landscape.

Whilst populations and locations of the Parks differ, their neighbouring communities are characterised by a number of similarities that can be linked to entrenched disadvantage: in South Africa, the legacies of apartheid (Sartorius et al. 2009) and, in Australia, legacies of socio-political and economic marginalisation of Indigenous people (Altman 2009). These legacies are evidenced by limited educational attainment, widespread poverty and unemployment. Warmun is characterised by welfare dependency (Doohan 2008), with $20.0 \%$ of the community receiving government benefits in 2007 (Warmun Community 2007). In the Bushbuckridge Local Municipality, which includes Cork and Belfast,

1.Kruger's northern and eastern boundaries form international borders and were no included in the scope of this research. unemployment often exceeds $90.0 \%$ and $84.0 \%$ of the population is classified as 'indigent', earning less than R1300 (\$169) per household per month (DWAF 2008). Educational statistics further illustrate community disadvantage. In Warmun, $22.0 \%$ of adults have never attended school (Taylor 2003). Similarly, only $1.7 \%$ of people residing in Bushbuckridge have received an education beyond high school level (Statistics South Africa 2007).

\section{Phase 2: Past system change}

Four drivers, three of them slow variables, had a significant influence on how the Parks, tourism and local communities interact: poverty, poor (Western) education levels and cultural norms and values based on a respect for nature. These slow variables exert a controlling influence over current system interactions. Economic opportunity associated with tourist arrivals was a fast variable, and the fourth driver, and potentially able to overwhelm the influence of the slower drivers. Each of these drivers influenced Park tourism impacts.

These drivers are largely beyond the control of local decisionmakers, as they represent fundamental, higher-scale processes not easily amenable to change by Park managers. The study communities are clearly characterised by disadvantage and underdevelopment. Poverty and poor (Western) education, for instance, reflect the legacies of past policies and practices of discrimination. Their influence is evident in the high incidence of unemployment in both study communities, as well as the entrenched welfare dependence in Warmun. In the communities around Kruger, there have been grant systems (e.g. for child support), a focus on education and economic development initiatives; however, poverty and disadvantage are still evident. Together, these two slow drivers were described by respondents as significant barriers to the ability of local communities to engage with Park tourism.

The third slow variable, cultural norms and values based on a respect for nature, was particularly evident in the Purnululu study. Indigenous respondents continually referenced enduring links between traditional culture and the physical landscape, emphasising the fundamental influence of such cultural norms on Indigenous worldviews. In the Kruger study, the influence of cultural norms on local interactions with Park tourism was unexpected yet clearly manifest in community responses. Respondents expressed a distinct respect for, and appreciation of, the natural environment and suggested that caring for such was integral to their way of life.

Governance issues related to power inequities and conflict over resources such as cultural sites, park access and natural resources were also a central concern for respondents in discussing Park-tourism-community interactions. Importantly, these governance elements were not fundamental determinants of interactions. Rather, they were themselves influenced by underlying drivers, such as a lack of the Western skills or education necessary for operating in a formal management environment, as identified in the Purnululu study. This 
vulnerability to drivers beyond the control of Park managers means that governance is considered a system characteristic rather than a driver.

\section{Phase 3: Current system state}

Three key issues are most pertinent to the impacts of Park tourism on local communities: nature conservation and intrinsic values, Park access and visitation, and employment. Community members were highly appreciative of links between Park tourism and the conservation of 'nature'. A range of intrinsic benefits were derived which appeared to foster positive attitudes towards the Parks and tourism. In the Kruger study, benefits centred on existence, aesthetic and bequest values.

Respondents reported personal benefits linked to opportunities to view natural landscapes and iconic wildlife species, as illustrated by the following quotation: 'The existence of [Kruger] itself I think people are benefitting because when they go there, they will see what they haven't seen outside' (Community member 73, male).

In contrast, respondents in the Purnululu study emphasised spiritual significance, although bequest values were also noted in relation to the transmission of cultural knowledge:

'Traditional country ... culturally ... gives people their identity, their family's identity, the connections, the stories, the beliefs ... country is very important ... [it] helps to define you as a person and to an extent your lifestyle and our values.' (Community member 8, female) (see Strickland-Munro \& Moore 2013:32)

This intrinsic appreciation of nature derives from, as well as contributes to, the identified slow driver of underlying cultural norms and values based on respect for nature.

The conservation of nature provided further (contested) benefits. These included the use and sale of natural resources such as fuel wood and medicinal plants. Respondents associated with Kruger linked this benefit to the ever-present demands of poverty and subsistence lifestyles: 'People see Kruger as a resource centre, where they can tap in for anything they want' (Park staff 5, female).

Community members were resentful of restrictions placed upon resource use by Park managers. A further contestation relevant to Kruger only was animals 'escaping' from the Park. This key Park tourism resource can cause significant destruction and sometimes deaths in local villages, negative impacts which can decisively influence local views of the Park and tourism associated with it. These negative impacts are compounded by complex, multi-stakeholder governance arrangements that restrict locals from dealing with escapee animals themselves: 'Villagers are not allowed to defend their property or commercial interests from the animals' (Tour operator 7 , male).

In many instances, however, community members appeared unwilling to discuss such animals in negative terms. Instead, they highlighted their appreciation of the Park and nature.
Benefits derived from the meat from escaped animals provide another explanation: 'Elephants and the other animals, they are not a problem because we get meat when [Kruger] kills them' (Community member 23, male).

Park access and visitation was a second key issue. Typically, community members lacked the physical and financial ability to visit their respective Parks. In the Kruger study, locals rarely visited the Park for pleasure. Most repeat visits were attributed to past or current employment or Park outreach programmes. In the Purnululu study, all community respondents had visited the Park previously but described significant difficulties in doing so. Poverty was central to these difficulties. Transport issues were the key limitation in both case studies, whereas Kruger respondents additionally cited the requirement to pay entrance fees. ${ }^{2}$ Community members described these barriers in the following ways: 'I do like to go to Purnululu, but how am I going to get there?' (Community member 5, female). 'I've never been inside Kruger. I've got no money to go in the gate' (Community member 17, female).

In both studies, access difficulties were linked to perceptions of disconnect from the Parks and tourism: 'The main purpose of Kruger is to conserve nature for the tourist to come and experience' (Community member 52, female).

Employment in Park tourism posed a third key issue and one directly related to the driver of 'economic opportunities associated with tourist arrivals'. Employment occurred in two ways: direct jobs in Park management or tourism operations and indirect employment involving the derivation of income from business or activities based on the Parks. Direct employment was limited in both studies. In the Purnululu study, only one local community member was employed in Park operations at the time of research. No community members were employed in tourism operations. In Kruger, nine community members were directly employed in varied Park and tourism operations. Such employment was highly valued by all community members on account of its ability to provide for family dependants and educational needs. However, a lack of skills required to successfully engage in formal Park and tourism roles precluded widespread benefit accrual, with benefits typically limited to those community members with the requisite skills and knowledge: 'It takes a fair bit of experience, knowledge and intent ... perhaps there aren't those people in Warmun' (Community member 10 , male).

Indirect employment associated with Park tourism was more prominent than direct employment in both studies. At Purnululu, one community member was employed at the Warmun roadhouse and a further four received income by selling Indigenous art. Home to a major art movement, a growing number of locals produce art for the Warmun Art Gallery. Although intermittent, income derived from sales can be substantial, often reaching tens of thousands of dollars.

2.Purnululu's management policy exempts local Indigenous community members from paying Park entrance fees. 
Artists receive $60 \%$ of the sale price, with $40 \%$ retained by the Gallery. Art production also provided significant intrinsic cultural benefits relating to maintenance of cultural connections to the country. At Kruger, 11 community members were indirectly employed in Park tourism through the selling goods at roadside stalls. Economic benefits derived from this activity were tempered by variability in tourist patronage: 'If tourists weren't driving up and down the road, those curio sellers wouldn't be there' (Tour operator 4, female).

In both studies, respondents described the interactions with tourists as limited. This limited interaction further contributed to a local disconnect from Park tourism.

\section{Ethical considerations}

Approval for this research was granted by the Murdoch University Human Research Ethics Committee, Permit No. 2007/153. Approval was also granted by the DEC's and Conservation's Nature Based Tourism and Recreation Research group, as well as the SANParks Research Board.

\section{Potential benefits and hazards}

No risks to interviewees were foreseen. All interviewees were guaranteed anonymity of data collected.

\section{Recruitment procedures}

Participation in the research was voluntary and interviewees were able to withdraw from the interview at any stage. Feedback was provided to interviewees at the end of the research process.

\section{Informed consent}

Interviewees were required to sign a consent form indicating their willingness to participate in the research.

\section{Data protection}

Interview data was securely stored on the passwordprotected computer of the first author. In accordance with ethical requirements, all data are securely kept for 7 years.

\section{Discussion}

Community benefits are obviously derived from tourism associated with the two case study Parks. These exist, however, alongside negative and contested impacts that highlight the complexity of interactions between Park tourism and local communities. The findings illustrate the influence of underlying fast and slow drivers on impacts experienced by the communities. The roles of historical contingency and cross-scale influences in determining current conditions are particularly evident.

\section{Nature conservation}

Community members derived clear intrinsic benefits from the natural Park environments. This was expected in the Australian context, where links between the physical environment and
Indigenous traditions are well established (Doohan 2008). Its presence in the Kruger study however was unexpected. The history of exclusion and separation associated with African conservation and South Africa's apartheid regime (Garland 2008; Kepe 2009) foster assumptions of an inherent disconnect. The results clearly refute this assumption. Instead, intrinsic benefits appear to provide local community members with a sense of stewardship for the Park and its tourism resources. This appreciation of intrinsic benefits challenges the wider African and broader global literature, which rarely highlights the significance of non-pecuniary benefits (Coad et al. 2008; Shackleton et al. 2008).

Use of natural resources and damage-causing animals were more tangible, and highly contested, impacts arising from nature conservation (and hence indirectly related to tourism) in the Kruger study. The use of natural resources by local communities appeared influenced by two key slow variables. Poverty, in terms of enduring livelihood pressures was central, indicating the ongoing influence of historic legacies. Cultural norms associated with respecting nature was a second slow variable influencing natural resource use. Locals linked their ability to harvest medicinal plants to intrinsic and tangible benefits associated with the maintenance of cultural traditions and knowledge, although, again, poverty has fostered contestation and resource demands that Park managers are unable to meet without causing significant ecological damage (L. Swemmer [SANParks] pers. comm., 12 September 2010).

Impacts associated with damage-causing animals challenge the intrinsic values attributed by community members to Kruger, fostering negative views towards the Park and its tourism. These negative views accord with other research linking such animals with reduced local support for protected areas (e.g. Madden 2004). This issue clearly illustrates the complexity of interactions between Kruger National Park and local communities and the impact of this issue on benefit perceptions. The socio-political realities that characterise community members in terms of poverty and poor Western education levels challenge their ability to dispute existing institutional arrangements governing management of damage-causing animals, to the ongoing detriment of Parkpeople relations.

\section{Park access and visitation}

Community members were constrained in their ability to visit the Parks for pleasure. Transport and monetary constraints were prominent barriers to further visitation, as commonly found in other research (e.g. Brown 2009; Simelane et al. 2006). Both barriers reflect the constraints imposed by entrenched poverty on local ability to benefit from Park tourism. In Kruger, access difficulties precluded opportunities to experience the Park as a 'tourist', a dichotomy wherein locals view their role as restricted to serving tourist needs rather than holding the right to enjoy Kruger as other people do. In Purnululu, access difficulties reduced community ability to maintain intrinsic benefits in 
terms of cultural connections to country. In both studies, access difficulties fostered perceptions of disconnect from the Parks, with an associated lesser appreciation of benefits. Visitation has been described as a privilege for rich (typically white) tourists (see also Novelli \& Scarth 2007; Simelane et al. 2006). For Kruger, this disparity is changing, with $29 \%$ of the 1132564 South African residents visiting this Park, as of April 2013, being black (SANPark 2013).

\section{Employment}

Employment in Park tourism presented a central point of benefit and contestation in both case studies. Clear benefits were realised and greatly appreciated by community members. Such benefits were limited in distribution to a minority of community members, as commonly reported in the wider literature (e.g. Simpson 2009; Trau \& Bushell 2008). It appears that whilst tourist arrivals bring potential for economic benefit, the underlying contexts of widespread poverty and poor Western education limit the ability of such benefits to permeate communities. These slow drivers restrict the capacity of community members to procure employment or start businesses to tap into tourism benefits.

These findings contribute to the growing body of literature contesting views of protected areas and tourism as 'money spinners' generating widespread financial benefits for local communities (Brockington et al. 2008). Pervasive expressions of disconnect from Park tourism evident from the interviews provide further support. In contrast, employment in the Purnululu study (both direct and indirect) provided intrinsic cultural benefits relating to connections to country. Thus again, interactions between Park tourism and local communities are seen as contested and complex in terms of benefit provision and influenced by historic and ongoing legacies that fundamentally shape current conditions and benefit accrual.

\section{Conclusion}

This study has provided in-depth insights into how local communities interact with, and benefit from Park tourism in South Africa and Australia. Research was guided by Strickland-Munro et al.'s (2010) resilience framework for investigating the relationship between Park tourism and local communities. Findings reveal a complex and contested picture whereby benefit derivation is juxtaposed against negative impacts. Benefit perceptions were influenced by four key underlying drivers: poverty, poor (Western) education levels, cultural norms and values based on a respect for nature, and economic opportunities associated with tourist arrivals. Although significant contextual differences exist, these drivers were common to both case studies and exerted a decisive influence over local perceptions and interactions with Park tourism. However, they are multi-scalar in origin and largely beyond the ability of local decision-makers to control. Their influence on perceptions of benefit was explored through three key issues identified by respondents: nature conservation, access difficulties and employment in Park tourism.
An important opportunity for local communities to benefit from Park tourism clearly centres on tangible economic benefits from employment, as commonly reported in the literature. In both studies, constraints are evident and reflect the ongoing influence of historical legacies of discrimination and marginalisation, entrained in the underlying slow variables of poverty and poor Western education. As such, caution is needed in advocating benefit opportunities, so as not to stimulate unrealistic community expectations. Simultaneously, Park and tourism managers must recognise the influence of historic legacies on the ability of community members to engage with available opportunities, working with communities over extended periods of time to build local capacity for involvement.

Evidence of intrinsic socio-cultural benefits derived from opportunities to experience 'nature' is an important finding. Such benefits were anticipated in the Australian context, yet unexpected in the Kruger study, where their identification challenges common assumptions regarding non-pecuniary benefits. The often-undervalued presence of cultural norms and values respecting nature potentially offers Park and tourism managers a promising and enduring platform for beneficial interactions between Park tourism and local communities. The complex nature of the relationships between communities and nature conservation in the Parks is illustrated by contestations over benefits and impacts associated with the use of natural resources and damagecausing animals at Kruger.

A second important finding arising from the research was the feeling of disconnect between community members and the Parks and their tourism. This disconnect likely stems from negative impacts associated with Park tourism, such as access difficulties and associated views of Park tourism as an activity reserved for rich or white tourists rather than locals. Cross-scale influences again appear to contribute, in the form of entrenched poverty and poor Western education, which, in turn, represent the legacies of policies and practices in South Africa and Australia. Pragmatic policy responses that seek to foster connections between locals and Park tourism, for instance alternative methods of facilitating visitation and, in Kruger, opportunities to experience the Park as a 'tourist', provide one means of reducing local disconnect.

In closing, a few comments on the conceptual framework are warranted. The framework proved valuable in accessing both local perspectives and multi-scalar influences, allowing the development of nuanced insights into the complexity of Park tourism impacts on local communities. Using an ethnographic approach provided valuable insights to the local communities; however, its combination with document reviews and interviews with stakeholders at broader scales was essential given the location of drivers beyond the local focal system. Applying this novel methodology to two iconic national parks and their communities has revealed the opportunities and challenges in progressing the well-being of these communities and their parks. This resilience approach 
has importantly exposed the complexity of such systems and through such exposure made an enhanced understanding and well-informed actions possible.

\section{Acknowledgements}

This research was supported financially by the Sustainable Tourism Cooperative Research Centre (established and funded by the Australian Government), the Western Australian Department of Environment and Conservation (WA DEC) and Murdoch University. Important and essential in-kind support was provided by WA DEC and SANParks. The intellectual and logistical contributions by Dr Stefanie Frietag-Ronaldson (SANParks) are gratefully acknowledged, as are the contributions of Drs Helen Allison and David Palmer, Murdoch University for their respective insights to systems thinking and Indigenous ways of knowing the world. Daryl Moncrieff, WA DEC also provided important support for and input to this research. The authors gratefully acknowledge the time and cooperation of respondents involved in this research.

\section{Competing interests}

The authors declare that they have no financial or personal relationships that may have inappropriately influenced them in writing this article.

\section{Authors' contributions}

J.S-M. (Murdoch University) was the principal investigator in this study and prepared the manuscript. S.M. (Murdoch University) contributed to research design and manuscript refinement.

\section{References}

Altman, J.C., 2007, Alleviating poverty in remote Indigenous Australia: The role of the hybrid economy, Centre for Aboriginal Economic Policy Research, Australian National University, Canberra.

Altman, J.C., 2009, Developing a national Indigenous policy framework that recognises needs, rights and legacies and delivers results, Centre for Aboriginal Economic Policy Research, Australian National University, Canberra.

Andereck, K.L., Valentine, K.M., Knopf, R.C. \& Vogt, C.A., 2005, "'Residents" perception of community tourism impacts', Annals of Tourism Research 32(4), 1056-1076.

Australian Bureau of Statistics, 2006, Housing and infrastructure in Aboriginal and Torres Strait Islander communities, Australia: Warmun community profile, Commonwealth of Australia, Canberra.

Binns, T. \& Nel, E., 2002, 'Tourism as a local development strategy in South Africa', The Geographical Journal 168(3), 235-247.

Bowen, G.A., 2008, 'Naturalistic inquiry and the saturation concept: A research note', Qualitative Research 8(1), 137-152.

Brockington, D., Duffy, R. \& Igoe, J., 2008, Nature unbound: Conservation, capitalism and the future of protected areas, Earthscan, London.

Brown, S., 2009, Protected landscapes and cultural and spiritual values, IUCN Protected Landscapes Task Force, Gland.

Bushell, R., Staiff, R. \& Eagles, P.F.J., 2007, 'Tourism and protected areas: Benefits beyond boundaries', in R. Bushell \& P.J.F. Eagles (eds.), Tourism and protected areas: Benefits beyond boundaries, pp. 1-11, CAB International, Wallingford.

Department of Conservation and Land Management, 1995, Purnululu National Park management plan 1995-2005, CALM, Perth.

Coad, L., Campbell, A., Miles, L. \& Humphries, K., 2008, The costs and benefits of forest protected areas for local livelihoods: A review of the current literature, UNEP World Conservation Monitoring Centre, Cambridge.

Cornelissen, S., 2005, The global tourism system: Governance, development and lessons from South Africa, Ashgate Publishing Limited, Aldershot.

Department of Environment and Conservation, 2008, 2008-2009 Annual report, DEC Perth.

Department of Environment and Conservation, 2012, 'Purnululu National Park visitor data', unpublished data, DEC, Perth.
Department of Water Affairs and Forestry, 2008, Bushbuckridge case study, DWAF, Durban.

Doohan, K., 2008, Making things come good: Relations between Aborigines and miners at Argyle, Backroom Press, Broome.

Farrell, B.H. \& Twining-Ward, L., 2005, 'Seven steps towards sustainability: Tourism in the context of new knowledge', Journal of Sustainable Tourism 13(2), 109-122.

Garland, E., 2008, 'The elephant in the room: Confronting the colonial character of wildlife conservation in Africa', African Studies Review 51(3), 51-73.

Kepe, T., 2009, 'Shaped by race: Why "race" still matters in the challenges facing biodiversity conservation in Africa', Local Environment 14(9), 871-878.

Kimberley Development Commission, n.d., The Kimberley, viewed 23 November 2012 from http://www.kdc.wa.gov.au/the-kimberly/

Kofinas, G.P. \& Chapin III, F.S., 2009, 'Sustaining livelihoods and human well-being during social-ecological change', in F.S. Chapin III, G.P. Kofinas \& C. Folke (eds.), Principles of ecosystem stewardship: Resilience-based natural resource management in a changing world, pp. 55-76, Springer, New York.

Madden, F., 2004, 'Creating coexistence between humans and wildlife: Global perspectives on local efforts to address human-wildlife conflict', Human Dimensions of Wildlife 9(4), 247-257

McCool, S.F., 2009, 'Constructing partnerships for protected area tourism planning in an era of change and messiness', Journal of Sustainable Tourism 17(2), 133-148.

Mill, R.C. \& Morrison, A.M., 2006, The tourism system, 5th edn., Kendall/Hunt Publishing Company, Dubuque.

Miller, F., Osbahr, H., Boyd, E., Thomalla, F., Bharwani, S., Ziervogel, G. et al., 2010, 'Resilience and vulnerability: Complementary or conflicting concepts?', Ecology and Society 15(3), Article 11.

Novelli, M. \& Scarth, A., 2007, 'Tourism in protected areas: Integrating conservation and community development in Liwonde National Park (Malawi)', Tourism and Hospitality Planning and Development 4(1), 47-73.

Phillips, A., 2003, 'Turning ideas on their head: The new paradigm for protected areas', The George Wright Forum 20(2), 8-32.

Plummer, R. \& Fennell, D.A., 2009, 'Managing protected areas for sustainable tourism: Prospects for adaptive co-management', Journal of Sustainable Tourism 17(2), 149-168.

QSR International, 2008, NVivo 8 [computer software], QSR International, Victoria.

Reinius, S.W. \& Fredman, P., 2007, 'Protected areas as attractions', Annals of Tourism Research 34(4), 839-854.

Resilience Alliance, 2007a, 'Assessing and managing resilience in social-ecological systems: A practitioner's workbook, vol. 1, version 1.0', viewed 31 July 2007, from systems: A practitioner's workbook, vol.
http://www.resalliance.org/3871.php

Resilience Alliance, 2007b, 'Assessing resilience in social-ecological systems: A scientist's workbook', viewed 31 July 2007, from http://www.resalliance.org/3871.php

Robinson, M., 1999, 'Cultural conflicts in tourism: Inevitability and inequality', in M. Robinson \& P. Boniface (eds.), Tourism and cultural conflicts, pp. 1-32, CAB Publishing, Wallingford

Sartorius, K., Sartorius, B., Tollman, S., Schatz, E., Kirsten, J. \& Collinson, M., 2009 The dynamics of rural poverty in a South African community: A spatial-temporal model, Institute of Behavioural Science, University of Colorado, Boulder.

Scherl, L.M. \& Edwards, S., 2007, 'Tourism, indigenous and local communities and protected areas in developing nations', in R. Bushell and P.F.J. Eagles (eds.), Tourism and protected areas: Benefits beyond boundaries, pp. 71-88, CAB International, Wallingford.

Shackleton, C., Shackleton, S., Gambiza1, J., Nel, E., Rowntree, K. \& Urquhart, P., 2008 Links between ecosystem services and poverty alleviation: Situation analysis for arid and semi-arid lands in southern Africa, Ecosystem Services and Poverty Reduction and semi-arid lands in southern Africa, Ecosystem Services
Research Programme, DFID, NERC, ESRC, South Africa.

Simelane, T.S., Kerley, G.I.H. \& Knight, M.H., 2006, 'Reflections on the relationships between communities and conservation areas of South Africa: The case of five South African national parks', Koedoe 49(2), 85-102.

Simpson, M.C., 2008, 'The impacts of tourism initiatives on rural livelihoods and poverty reduction in South Africa: Mathenjwa and Mqobela', in A. Spenceley (ed.), Responsible tourism: Critical issues for conservation and development, pp. 239-266, Earthscan, London.

Simpson, M.C., 2009, 'An integrated approach to assess the impacts of tourism on community development and sustainable livelihoods', Community Development Journal 44(2), 186-208.

South African National Parks, 2008, Kruger National Park management plan, SANParks, Pretoria.

South African National Parks, 2011, Annual report 2010/11, SANParks, Pretoria.

South African National Parks, 2013, 'Guest access data', unpublished internal report, SANParks, Pretoria.

Statistics South Africa, 2007, Community survey 2007, revised edn., Statistics South Africa, Pretoria.

Strickland-Munro, J.K., Allison, H.E. \& Moore, S.A., 2010, 'Using resilience concepts to investigate the impacts of protected area tourism on communities', Annals of Tourism Research 37(2), 499-519.

Strickland-Munro, J.K. \& Moore, S.A., 2013, 'Indigenous involvement and benefits from tourism in protected areas: A study of Purnululu National Park and Warmun Community, Australia', Journal of Sustainable Tourism 21(1), 26-41.

Taylor, J., 2003, Aboriginal population profiles for development planning in the Northern East Kimberley, Centre for Aboriginal Economic Policy Research, Australian Nationa University, Canberra. 
Telfer, D.J. \& Sharpley, R., 2008, Tourism and development in the developing world, Routledge, London.

Trau, A. \& Bushell, R., 2008, 'Tourism and indigenous people', in S.F. McCool \& R.N. Moisey (eds.), Tourism, recreation and sustainability: Linking culture and the environment, 2nd edn., pp. 260-282, CABI, Wallingford.

Tourism Research Australia, 2009, Nature tourism fact sheet, viewed 27 September 2012, from http://www.ret.gov.au/tourism/Documents/tra/Snapshots\%20and\%20 Factsheets/Nature_factsheet_FINAL.pdf

UNESCO, 2010, Purnululu National Park, viewed 08 February 2010, from http://whc. unesco.org/en/list/1094
Urban-Econ, 2008, SANParks: Economic impact assessment, SANParks, Pretoria.

Walker, B.H., Anderies, J.M., Kinzig, A.P. \& Ryan, P., 2006, 'Exploring resilience on social-ecological systems through comparative studies and theory development: Introduction to the special issue', Ecology and Society 11(1), Article 12.

Wall, G. \& Mathieson, A., 2006, Tourism: Changes, impacts and opportunities, Pearson Prentice Hall, New York.

Warmun Community (Turkey Creek) Inc. 2007, Community corporate planning and management guide 2007-2010, Warmun Community (Turkey Creek) Inc., Warmun.

Worboys, G.L., Lockwood, M. \& De Lacy, T., 2005, Protected area management: Principles and practice, 2nd edn., Oxford University Press, South Melbourne. 